\title{
Ihmiselämä kapitalistisessa tuotantoketjussa
}

Kristiina Brunila, Jussi Onnismaa ja Heikki Pasanen (toim.) (2015). Koko elämä töihin.

Koulutus tietokykykapitalismissa. Tampere: Vastapaino. 346 s. ISBN 978-951-768-533-7

KOKO ELÄMÄ TÖIHIN, joka on myös Aikuiskasvatuksen 52. vuosikirja, kuvaa työtä ja koulutusta tietokykykapitalismissa. Postfordistisessa yhteiskunnassa tiedosta ja tiedontuotannosta on tullut keskeinen varallisuuden kerryttämisen väline. Tietokykykapitalismi tarkoittaa niitä tapoja, joilla ihmisten tietämisen kyvyt valjastetaan talouden palvelukseen.

Teoksessa tarkastellaan eri näkökulmista sitä, kuinka koulutus ja työelämä otetaan osaksi tietokykykapitalismin tuotantoketjua ja mitä siitä seuraa. Teos jakautuu viiteen osaan, jotka pitävät sisällään yhteensä yksitoista artikkelia.

\section{MIKÄ TIETOKYKYKAPITALISMI?}

Ensimmäinen osa on teoreettismetodologinen johdanto tietokykykapitalismin käsitteeseen ja sen tutkimukseen. Avausartikkelissa kirjan toimittajat avaavat tietokykykapitalismin, työn ja koulutuksen liittoa. Työ perustuu yhä enemmän yleisiin kykyihin, joita käytetään muuallakin kuin työelämässä. Siksi tietokykykapitalismissa hallinta ja kontrolli eivät kohdistu vain työhön tai koulutukseen, vaan paitsi työstä ja koulutuksesta vapaaseen aikaan, myös ihmiseen kokonaisuudessaan.

Teoksen muiden osioiden artikkelit avaavat tätä ilmiötä eri näkökulmista. Johdannossa kerrotaan artikkelien ottavan tietokykykapitalismin tarkastelun lisäksi esiin näkökulman, miten todellisuudet voisi rakentaa toisin. Tämä tavoite jää kuitenkin joissakin artikkeleissa uupumaan, eikä vastarinnan mahdollisuuksille jää lopulta kovinkaan suurta roolia kirjassa.

Ensimmäisen osan kaksi muuta artikkelia kuvaavat talouden, tiedon, työn ja koulutuksen kytkeytymistä toisiinsa käsitteellisellä tasolla. Artikkelit muodostavat yhtenäisen kokonaisuuden ja samalla kirjan teoreettisimman annin.

Tekstien lukijaystävällisyyttä olisi hieman voinut parantaa helpommilla ilmaisuilla ja anglismeja, eli englannin kielestä lainattuja sanoja, karsimalla. Empiirisemmissä artikkeleissa määritellään tietokykykapitalismi selvästi yleistajuisemmin. Tämä on myös yksi teoksen ongelma: tietokykykapitalismin määrittelyt eivät ole yhdenmukaisia, ja osassa artikkeleista suhde käsitteeseen jää etäiseksi.

\section{LISÄÄ TILAA VASTARINNALLE}

Toinen osa on nimeltään Tietokykykapitalismi menee kouluun. Sen kahdessa artikkelissa tarkastellaan tietokykykapitalismia teknologian ja yrittäjyyskasvatuksen näkökulmista. 
Ne kuvaavat hyvin koulujen ristiriitaista asemaa tietokykykapitalismissa. Yhtältä koulun asema tietokykykapitalismin vaatimien pätevyyksien tuottamisessa on keskeinen, toisaalta koulu ei alkuunkaan tunnu pysyvän mukana muutosten vauhdissa.

Muutoksia arvioidaan tutkijoiden näkökulmista,, mutta olisi kiinnostavaa tutustua myös opettajien ja oppilaiden näkemyksiin ja rooliin kehityksessä, jossa ihmiselämä valjastetaan yhä suuremmassa määrin taloudellisen tuottavuuden välineeksi. Kiinnostava kysymys olisi myös se, antaako opettajankoulutus minkäänlaisia valmiuksia opettajille toimia uusliberalistisen koulutusdiskurssin haastajina.

Kolmas ja neljäs osa, Yliopisto tietomarkkinoilla ja Tulos tai ulos, tarkastelevat osin samoja aiheita: yliopiston ja korkeakoulutuksen roolia tietokykykapitalismissa.

Yliopisto käy läpi rakenteellista ja kulttuurista muutosta, joka on tietokykykapitalismille otollinen. Tieto, tutkimus ja oppiminen pyritään uudessa yliopistossa tekemään tehokkaaksi ja taloudellisesti tuottavaksi toiminnaksi. Artikkeleissa katse kohdistuu niihin vaatimuksiin, joita nämä muutokset yksilöille asettavat: itsen muokkauksesta akateemisille työmarkkinoille sopivaksi yksilöksi tulee elämänmittainen projekti.

Näihin osioihin olisimme erityisesti kaivanneet rinnalle näkökulmia, joissa avataan tilaa vastarinnan mahdollisuuksille ja toisin tekemisen paikoille. Poikkeuksen tekee Hanna Kuuselan artikkeli, jossa hän pyrkii tekstinsä lopussa avaamaan mahdollisuuksia tiedon irrottamiselle voitontavoittelusta.

\section{YDINKYSYMYSTEN ÄÄRELLÄ}

Teoksen päättää viides osa Kun kontrolli leviää koko elämän aikaan. Osio on kirjan epäyhtenäisin kokonaisuus sekä teemoiltaan että kirjoitustyyleiltään. Janne Kurki ottaa nykymedian negatiivisia vaikutuksia nuoriin ja lapsiin tarkastelevassa tekstissään kantaa siihen, miten vanhempien olisi toimittava kaikkialle tunkevan yksilömedian puristuksessa.

Väheksymättä Kurjen esille nostamia ongelmia ja hänen käytännön työssään kohtaamiensa tapausten surullisuutta epäilemme, että Kurjen laatimat peukalosäännöt eivät vakuuta lukijoita - etenkin, kun artikkelin teoriapohja on ohut.

Olisiko lapsen sosiaalisen eristämisen sijaan, mihin esimerkiksi älypuhelimen kieltäminen alle 16-vuotiaalta todennäköisesti johtaisi, järkevämpää opettaa hänelle turvallista älypuhelimen käyttöä ja itsensä suojaamista nykymedian haitallisilta vaikutuksilta? Lasten nykymedian käyttö ei ole Kurjen osoittamalla tavalla vanhempien kontrollissa, vaikka kuinka noudattaisi hänen laatimiaan ohjeita.

Teoksen viimeisenä artikkelina on Mikko Jakosen kirjan teemoja yhteen vetävä teksti, joka on yksi kokoelman helmistä. Pohtiessaan työelämän ja koulutuksen käynnissä olevia muutoksia yhteiskunnan ja työelämän prekarisoitumi- sen aiheuttamaa pelkoa vasten Jakonen on teoksen ydinkysymysten äärellä.

Jälkikapitalistinen talous on pelon taloutta, ja pelko ei rajoitu vain työhön tai työttömyyteen, vaan tunkeutuu kaikille elämänalueille. Tämän mahdollistaa teoksen muissa artikkeleissa monipuolisesti avattu työn muutos. Työnantajalle ei tarjota vain työpanosta, vaan koko osaamisen potentiaali. Kirjoittaja päättää artikkelinsa ja samalla koko kirjan kaikkien kasvatustieteilijöiden kannalta äärimmäisen tärkeään huomioon: "Tietokapitalismin aikakaudella koulutukseen liittyvät perustavat ja radikaalit kysymykset on kysyttävä jälleen undelleen" (s.311).

\section{KIRJOITTAJIEN TAUSTAT ESIIN}

Teos kärsii jonkin verran artikkelikokoelmille tyypillisestä ongelmasta: artikkelit eivät ole tasalaatuisia. Joukossa on todella kiinnostavia puheenvuoroja ja tiukkoja teoreettisia analyysejä, mutta myös pari tekstiä, jotka eivät tieteellisellä annillaan ja argumentaatiollaan vakuuta.

Teoksen toimittajia tai artikkelien kirjoittajia ei esitellä teoksessa ollenkaan, mikä on monitieteisessä kokoelmassa ongelmallista. Lukijan täytyy itse mielessään kontekstualisoida keskenään hyvin erilaisissa teoriaperinteissä liikkuvat tekstit. Osa teksteistä näyttää rakentuvan kirjoittajansa kokemusasiantuntijuuden varaan, mutta jää epäselväksi, millaisesta teoreettismetodologisesta positiosta käsin kirjoittajat maailmaa katsovat. 
Kirja on arvokas lisä keskusteluun talouden, koulutuksen ja ihmisen tietokyvyn suhteesta. Hieman pidemmälle viedyllä toimitustyöllä se tarjoaisi lukijalle jäsentyneemmän, luettavamman ja puhuttelevamman lukukokonaisuuden. Pääosin artikkelit ovat varsin kiinnostavia ja avaavat tärkeällä tavalla ajassamme liikkuvia kehityskulkuja ja niiden uhkia.

\section{Katri Otonkorpi-Lehtoranta YTM, tutkija Työelämän tutkimuskeskus Tampereen yliopisto}

Hanna Ylöstalo

YTT, vanhempi tutkija Nuorisotutkimusverkosto 